\title{
Biometry and germination of Balfourodendron riedelianum Eng. Eng.1
}

\author{
Daniele Rodrigues Gomes ${ }^{2 *}$, Maristela Machado Araujo², \\ Ubirajara Rossi Nunes ${ }^{2}$, Suelen Carpenedo Aimi
}

\begin{abstract}
This study investigated the biometry, pre-germination treatments and substrates for the germination of diaspores of Balfourodendron riedelianum. The diaspores were characterized during germination according to their length, width, thickness, thousand kernel weight (TKW) and water content. Dormancy overcoming was tested by diaspore scarifying with sandpaper, sulfuric acid immersion, water and water at $100^{\circ} \mathrm{C}$; together with the control (untreated), they were associated to different substrates (including paper (EP), sand (EA) and vermiculite (EV). Germination tests were conducted in a germination chamber at $25^{\circ} \mathrm{C}$. The physiological quality of seeds was performed through the first count, germination and germination speed index (GSI). Biometric data were analyzed in frequency classes and the pre-germination treatment by analysis of variance. Diaspores are on average $18.59 \mathrm{~mm}$ long; $9.03 \mathrm{~mm}$ wide and $9.38 \mathrm{~mm}$ thick. The treatment of immersion in cold water for 48 hours and the substrate vermiculite (EV) were effective to overcome dormancy and recommended for germination tests.
\end{abstract}

Index terms: seed analysis, morphology, dormancy, forest species.

\section{Biometria e germinação de Balfourodendron riedelianum Eng. Eng.}

\begin{abstract}
RESUMO - O presente trabalho objetivou estudar a biometria, tratamentos pré-germinativos e substratos para germinação de diásporos de Balfourodendron riedelianum. Os diásporos foram caracterizados na germinação quanto ao comprimento, largura, espessura, peso de mil sementes (PMS) e teor de água. Foram empregados os métodos de escarificação com lixa e ácido sulfúrico, imersão em água fria e em água a $100{ }^{\circ} \mathrm{C}$, e o controle (sem tratamento), associados a diferentes substratos (entre papel (EP), entre areia (EA) e, entre vermiculita (EV), sendo conduzidos em câmara de germinação a $25^{\circ} \mathrm{C}$. A caracterização fisiológica foi realizada por meio da primeira contagem, germinação e índice de velocidade de germinação (IVG). Os dados biométricos foram analisados em classes de frequências e os tratamentos pré-germinativos por meio da análise de variância. Os diásporos apresentam em média 18,59 mm de comprimento; 9,03 $\mathrm{mm}$ de largura e 9,38 mm de espessura. O tratamento de imersão em água fria por 48 horas e o substrato entre vermiculita (EV) foi efetivo para a superação da dormência e o mais adequado para o teste de germinação da espécie.
\end{abstract}

Termos para indexação: análise de sementes, morfometria, dormência, espécie florestal.

\section{Introduction}

Balfourodendron riedelianum Eng. Eng. (Rutaceae family), known as Brazilian maple and ivory maple, is a forest species native from Brazil. Since it is not endemic, its propagation occurs through seeds; however, due to the difficulty in removing the seeds from inside the fruits, they are used as propagules in seedling nurseries. Brazilian maple is a species that can be used as wood resource, for landscaping purposes and for the recovery of riparian degraded areas; during its adult stage, it reaches from 6 to $30 \mathrm{~m}$ of height and 30 to $90 \mathrm{~cm}$ of diameter, and in some cases, it may reach $35 \mathrm{~m}$ and $100 \mathrm{~cm}$, respectively (Backes and Irgang, 2002; Carvalho, 2003; Lorenzi, 2008). Despite the appealing characteristics of the species, the lack of information on its propagation makes it harder for it to be used, and it is fundamental to conduct studies through germination analysis, production of seedlings and in-field growth, allowing its use on forestry programs.

Studies related to the biometry of the diaspores, methods to overcome dormancy, need for light, water, temperature and substrate are fundamental to know the germination process of vegetable species. The inherent knowledge to the germination process regarding the size of diaspores, water content, dormancy overcoming, substrate, among others, are

${ }^{1}$ Submitted on 02/01/2016. Accepted for publication on 06/02/2016.

${ }^{2}$ Departamento de Ciências Florestais, Universidade Federal de Santa Maria, 97105-900 - Santa Maria, RS, Brasil.

*Corresponding author <eng.danielegomes@gmail.com> 
important information for the propagation of forest species; however, they may vary from species to species.

The methods to conduct the germination tests are shown on the Rules for Seed Testing (RAS) (Brasil, 2009), and through the Guidelines for the Analysis of Seeds of Forest Species (Brasil, 2013). The latter contemplates 319 forest species; however, among them, only 50 have validated tests (Brasil, 2010; Brasil, 2011; Brasil, 2012). However, Balfourodendron riedelianum is not among the group of validated species, showing the lack of studies on this species.

The study on whether the dormancy of the seeds occurs or not is vital, since it is common on several forest species. There are several manners for the manifestation of dormancy and to determine the methods to overcome it, depending on the endogenous and exogenous dormancy methods. Biruel et al. (2007) used a mechanical scarification to overcome the dormancy of seeds of Caesalpinia leiostachya, Oliveira et al. (2012) used chemical and mechanical scarification to overcome the physical dormancy on seeds of Parkia gigantocarpa, Seneme et al. (2012) and Alexandre et al. (2015) used physical and chemical treatments on seeds of Peltophorum dubium and Enterolobium contortisiliquum, respectively. In addition, methods such as immersion on hot water (Azeredo et al., 2010) and the use of hormones, such as gibberellic acid, may also be used (Campos et al., 2015).

For the germination of the seeds, each species requires specific conditions regarding its hydration, aeration, temperature and luminosity. Nogueira et al. (2014) and Godoi and Takaki (2004) evaluated the light and temperature effects on seeds of Piptadenia stipulacea and Cecropia hololeuca, respectively, and determined that the germination is indifferent to luminosity, and that the best temperatures are between 20 and $30^{\circ} \mathrm{C}$ on a constant or alternating basis, while seeds of $C$. hololeuca germinated in the dark when the temperature was alternated (20-25; 20-30 and 20-35 $\left.{ }^{\circ} \mathrm{C}\right)$. Dresch et al. (2012) evaluated the influence of the temperature and humidity of the substrate on the germination of seeds of Campomanesia adamantium and reached a substrate humidity of 2.5 times the mass of the dry paper, at a temperature of $25^{\circ} \mathrm{C}$.

In that sense, the substrate acts directly, due to its physical functions related to the structure, aeration, capacity to retain water, propensity to infestation by pathogens, among others (Martins et al., 2012). Santos and Aguiar (2000), when evaluating the germination of seeds of Sebastiania commersoniana due to the substrate and the temperature regimen, observed that the most adequate substrate was on sand, which offered maximal germination, at an alternating temperature of $20-30{ }^{\circ} \mathrm{C}$. Guedes et al. (2010), when evaluating substrates and temperature to test the germination and vigor of seeds of Amburana cearensis, concluded that the temperature of $35^{\circ} \mathrm{C}$ was the most adequate to conduct the tests, regardless of the substrate used.

On the Rules for Seed Testing, some substrates are recommended, such as paper (buffer, towel and filter), sand and soil (Brasil, 2009). However, for most forest species, there are no standardized procedures, and other substrates have been tested, as it is the case of vermiculite (Brasil, 2013).

Considering the above, the objective of this paper was to study aspects of the biometry, stablishing pre-germination treatments and determining the substrates that favor the germinability of diaspores of Balfourodendron riedelianum, a potential species for forestry activities.

\section{Material and Methods}

The diaspores (fruits) of Balfourodendron riedelianum were collected in July, 2013, from four matrix trees in forest fragments located in the district of Caemborá $\left(29^{\circ} 28^{\prime} 18.9^{\prime \prime} \mathrm{S}\right.$ and $53^{\circ} 18^{\prime} 03.4^{\prime \prime} \mathrm{W}$ ), in the municipality of Nova Palma, RS, Brazil. Due to the lack of uniformity on the fructification, the standard used were matrixes that showed similar characteristics as to the fruit maturation, when they changed from the green color (2.5GY 5/4) to beige-yellow (2.5Y 7/6). The coloration of the diaspores was determined based on the chart of colors of vegetable tissue (Munsell, 1976).

After the collection, the material was stored on individualized plastic bags identified by matrix, and transported to the forest seedling nursery. There, the diaspores went through natural pre-drying in a covered location with air circulation $\left(19^{\circ} \mathrm{C}\right.$ and $\left.75.8 \% \mathrm{RH}\right)$, and they were arranged on trays placed on tables, for three days, with daily turning over. This material was processed in order to remove branches and leaves. Then, the winged part of the diaspore was removed, with the help of pruning shears. The use of diaspores for the laboratory tests is due to the difficulty in removing the seeds from them without compromising and/or damaging the structure of the embryo.

After processing, the seed lot with the diaspores was constituted, and they were allocated into two paper packages, inside kraft paper cylinders, stored in a cold and moist chamber (temperature $\pm 8{ }^{\circ} \mathrm{C}$ and relative humidity (RH) around $80 \%$ ).

\section{Lot characterization}

A sample was collected before storage in order to characterize the diaspores according to Rules for Seed Testing (Brasil, 2009) and the Guidelines for the Analysis of Seeds of Forest Species (Brasil, 2013). In order to determine one thousand diaspores weight (TDW), eight replications of 100 diaspores were used, obtaining results expressed in grams. The evaluation of the water content was conducted using the oven method, at $105^{\circ} \mathrm{C}( \pm 3)$ 
for 24 hours, with two replications of approximately five grams of intact diaspores, and the results were expressed based on the humid weight of the diaspores (Brasil, 2009).

The biometric description of the diaspores was conducted using 100 units, randomly removed from the lot (five replications with 20 diaspores), measuring the length ( $\mathrm{mm})$, width $(\mathrm{mm})$ and thickness $(\mathrm{mm})$, obtained with a digital caliper rule (precision of $0.01 \mathrm{~mm}$ ).

\section{Pre-germination treatments}

The germination test was conducted in the laboratory. Initially, the superficial asepsis was done, which consisted in the immersion of the diaspores in alcohol $70 \%$ and in a commercial sodium hypochlorite solution $(2.5 \% \mathrm{Cl})$ at $1 \%$ $(\mathrm{p} / \mathrm{p})$, consecutively, both for two minutes; then, they were washed in distilled water for two minutes.

The pre-germination treatments were: Control - consisting of intact diaspores; Immersion in water - immersion in cold water at $10{ }^{\circ} \mathrm{C}$ for 24,36 and 48 horas; Immersion in boiling water - immersion in water at a temperature of $100^{\circ} \mathrm{C}$ for five minutes; Chemical scarification in sulphuric acid $\left(\mathrm{H}_{2} \mathrm{SO}_{4}^{-}\right)$for five minutes, followed by rinsing in running water to remove the residues, for two minutes; Mechanical scarification with sandpaper n. 60 on the opposed region to the peduncle; Mechanical scarification with sandpaper, followed by immersion in water at room temperature $\left(19{ }^{\circ} \mathrm{C}\right)$ for 24 hours; Mechanical Scarification with sandpaper, followed by immersion in gibberellic acid $\mathrm{GA}_{3}$ at a concentration of $500 \mathrm{mg} \cdot \mathrm{L}^{-1}$. The $\mathrm{GA}_{3}$ solution was prepared according to the methodology described by Brasil (2009).

The feasibility of the diaspores was determined through the germination test. After the pre-germination treatments, four replications with 20 diaspores were planted on three different substrates: sand, vermiculite and paper, arranged on transparent plastic boxes with the following dimensions: 11 $\mathrm{cm} \times 11 \mathrm{~cm} \times 3.5 \mathrm{~cm}$.

Previously to the germination test, the substrates were sterilized on an autoclave $\left(120^{\circ} \mathrm{C}\right.$ for 60 minutes) and, afterwards, they were taken to the forced air circulation oven at $70{ }^{\circ} \mathrm{C}$ for two hours and 24 hours, for the drying of the paper, vermiculite and sand, respectively. The sand and vermiculite substrates were moistened with distilled water at $60 \%$ of their retention capacity, which corresponded to 43 and $47 \mathrm{~mL}$, respectively, while the paper substrate was moistened with distilled water at a quantity equivalent to 2.5 times the dry mass of the paper, which is equivalent to $14 \mathrm{~mL}$ (Brasil, 2013).

The plastic boxes were maintained in Mangelsdorftype germination chambers, at a temperature of $25\left( \pm 1^{\circ} \mathrm{C}\right)$ and photoperiod of 8-16 hours (light/dark). The evaluations were conducted at every three days, between the $18^{\text {th }}$ and the $45^{\text {th }}$ day, a period that corresponds to the beginning and the stabilization of the germination. The seedlings that were considered as normal were the ones that showed all the essential structures (primary root, hypocotyl, cotyledons and epicotyl), and the seedlings considered as abnormal were the ones that did not show all of these structures, according to the photographic record (Figure 2) (Brasil, 2009).

The diaspore was considered a multiple seed unit (MSU), considering that it may produce more than one normal seedling. Therefore, when the diaspore (seed unit) produced more than one seedling (normal or abnormal), only the first one to germinate was counted in order to determine the germination percentage. The diaspores considered as hard diaspores were the ones that did not show at least one seedling. The results were expressed in germination percentage (Brasil, 2009) and the germination speed index (GSI), determined according to the formula suggested by Maguire (1962).

\section{Experimental design and data analysis}

The biometry data of the diaspores were analyzed by the adjustments of statistical distributions and descriptive statistics, which comprehended position measurements (mean) and dispersion measurements (variation coefficients) (Silva et al., 2013).

The pre-germination treatment data were conducted on a completely randomized design (CRC) with four replications, on a 9 x 3 factorial (overcoming of dormancy x substrate). They were evaluated as to the normality assumptions of the residues, according to the Shapiro-Wilk test, and variance homogeneity, according to the Bartlett test. When not met, they were subjected to data transformation, considering the water content, germination percentage, hard diaspores on arcsine $\sqrt{\mathrm{x} / 100}$; GSI and abnormal seedlings $\sqrt{x+0.5}$, considering $\mathrm{x}$ as the value obtained for the observed variable. The transformed data was used only for the statistical analysis, and the original data was maintained for the presentation of the results.

The statistical analysis was conducted with the help of the SISVAR software (Ferreira, 2011), subjecting the data to analysis of variance (ANOVA) and, when a difference was observed among the treatments, the means were compared by the $t$ and Scott-Knott tests at $5 \%$ of error probability.

\section{Results and Discussion}

The lot constituted by $B$. riedelianum diaspores showed one thousand diaspores weight (TDW) value of $361.43 \mathrm{~g}$ with a variation coefficient ( $\mathrm{VC}$ ) of $2.61 \%$, which is equivalent to 2,766 fruits per kilogram, and moisture content of $17.13 \%$. 
When studying the species, Donazzolo et al. (2013) found a humidity equivalent to $14.7 \%$, and the thousand kernel weight showed similar results than the ones observed by Lorenzi (2008) and Grings and Brack (2011), with values that varied between 2,200 and 2,900 fruit. $\mathrm{Kg}^{-1}$ and 2.460 fruit. $\mathrm{Kg}^{-1}$, respectively.

This variation on the water content of the diaspores, as well as on the thousand kernel weight, may be associated to different factors, such as, for example, the genotype and the origin region. The quality and vigor obtained from the lot sample are directly related to the dimensions of the diaspores, and they are associated not only to environmental factors, but also to the reactions of the population to the establishment on a new environment, mainly when the species has a broad distribution (Rodrigues et al., 2006).

The frequency distribution of the biometric data of the diaspores of $B$. riedelianum, in relation to the length and width, showed means of $18.59 \pm 1.71 \mathrm{~mm}$ for length; $9.03 \pm 1.12 \mathrm{~mm}$ for width, and $9.38 \pm 1.40 \mathrm{~mm}$ for thickness (Figure 1). The most representative frequency class was $19.87-21.57 \mathrm{~mm}$ (41\%) for length; 9.51-10.38 mm (36\%) for width, and 10.87-11.96 $\mathrm{mm}(28 \%)$. These results are similar to the interval determined by Carvalho (2003), when characterizing the diaspore of $B$. riedelianum, during its mature phase, with dimensions that vary from 5 to $25 \mathrm{~mm}$ wide by 20 to $25 \mathrm{~mm}$ long. However, they were superior than the observed by Grings and Brack (2011) for the species, with biometric values that vary from 3 to $4 \mathrm{~cm}$ long and 2.5 to $3.0 \mathrm{~cm}$ wide.
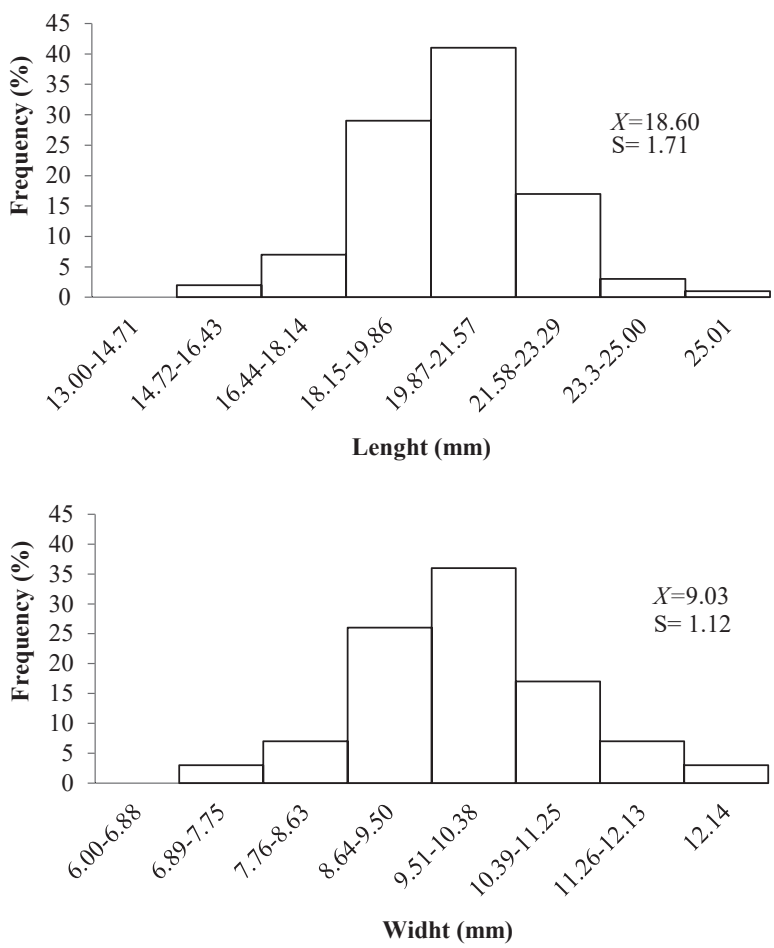

(A)

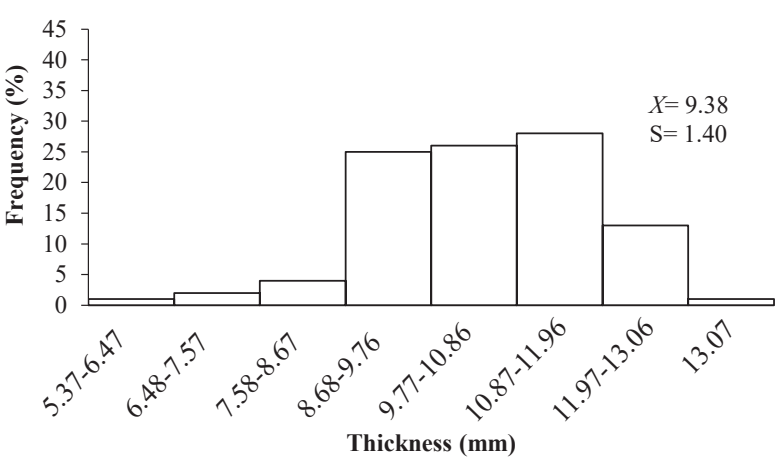

(B)

(C)

Figure 1. Frequency, mean $(X)$ and standard deviation $(\mathrm{S})$ of the length $(\mathrm{A})$, width $(\mathrm{B})$, and thickness $(\mathrm{C})$ of the diaspores of Balfourodendron riedelianum. 
The position of the seed on the mother plant may affect the size, morphology and germination, which is mediated by environmental factors that act during the development and maturation of the fruit (Gutterman, 1992). The biometric characteristics of the diaspores show little variation, as it may be observed by the standard deviation, varying from 13.24 to $24.1 \mathrm{~mm}$ (1.82 times) in length and 6.05 to $12.18 \mathrm{~mm}$ (2.01 times) wide, respectively, which may be a reference that indicates diaspores collected on the region of Nova Palma, RS.

\section{Physiological characteristics}

On the analysis of variance of the data, a significant interaction was observed among pre-germination treatments and substrates for the germination and germination speed index variables; however, for the abnormal seedling and hard diaspores, there was a significant effect only of the dormancy overcoming treatments. For the first counting variable, the descriptive analysis of the data was conducted.

The germination is epigeal phanerocotylar, starting on the $18^{\text {th }}$ day after the installation of the test, a period in which it was possible to conduct the first counting. The first seedlings were observed on the treatments with immersion in cold water for 24 and 48 hours, on the vermiculite and sand substrates, and the last substrate was only for immersion for 48 hours. The germination stabilization occurred on the $45^{\text {th }}$ day. Brasil (2013) and Figliolia and Piña-Rodrigues (1995) recommend that the first counting for $\mathrm{B}$. riedelianum is conducted on the $20^{\text {th }}$ to the $25^{\text {th }}$ day after installing the test; on this study, the sample used allowed this evaluation to be conducted within a shorter period of time, after overcoming the dormancy imposed by the membrane.

Based on the data related to the germination percentage means of the diaspores of $B$. riedelianum, higher values were observed on the treatment with immersion in water for $48 \mathrm{~h}$, regardless of the substrate used (Table 1). The pre-germination treatments, immersion in boiling water and sulphuric acid for five minutes, regardless of the substrate, did not offer the germination process of the seeds, which occurred only when the diaspores were treated with sulphuric acid and cultivated on vermiculite $(9 \%)$.

Table 1. Pre-germination treatments on diaspores of Balfourodendron riedelianum associated to different substrates as the index of physiological quality through the following variables: germination and germination speed index (GSI).

\begin{tabular}{|c|c|c|c|}
\hline \multicolumn{4}{|c|}{ Germination $(\%)$} \\
\hline \multirow{2}{*}{ Treatments } & \multicolumn{3}{|c|}{ Substrate } \\
\hline & Paper & Sand & Vermiculite \\
\hline Control & $51 \mathrm{Bb}$ & $51 \mathrm{Bc}$ & $73 \mathrm{Aa}$ \\
\hline Immersion on cold water $10^{\circ} \mathrm{C}$ for $24 \mathrm{~h}$ & $56 \mathrm{Bb}$ & $62 \mathrm{Bb}$ & $79 \mathrm{Aa}$ \\
\hline Immersion on cold water $10^{\circ} \mathrm{C}$ for $48 \mathrm{~h}$ & $80 \mathrm{Aa}$ & $84 \mathrm{Aa}$ & $83 \mathrm{Aa}$ \\
\hline Immersion on cold water $10^{\circ} \mathrm{C}$ for $72 \mathrm{~h}$ & $61 \mathrm{Ab}$ & $49 \mathrm{Ac}$ & $60 \mathrm{Ab}$ \\
\hline Immersion on boiling water at $100^{\circ} \mathrm{C} 5 \mathrm{~min}$ & $0 \mathrm{Ae}$ & 0 Ad & $0 \mathrm{Ae}$ \\
\hline Chemical scarification with sulphuric acid $5 \mathrm{~min}$ & $0 \mathrm{Be}$ & $0 \mathrm{Bd}$ & 9 Ad \\
\hline Mechanical scarification with sandpaper & $31 \mathrm{Bd}$ & $34 \mathrm{Bc}$ & $53 \mathrm{Ab}$ \\
\hline Mechanical scarification with sandpaper and immersion on water for $24 \mathrm{~h}$ & $46 \mathrm{Ac}$ & $46 \mathrm{Ac}$ & $55 \mathrm{Ab}$ \\
\hline Mechanical scarification with sandpaper and immersion on $\mathrm{GA}_{3}$ & $43 \mathrm{Ac}$ & $44 \mathrm{Ac}$ & $33 \mathrm{Ac}$ \\
\hline \multicolumn{4}{|l|}{ GSI } \\
\hline \multirow{2}{*}{ Treatments } & \multicolumn{3}{|c|}{ Substrate } \\
\hline & Paper & Sand & Vermiculite \\
\hline Control & $0.47 \mathrm{Ac}$ & $0.49 \mathrm{Ac}$ & $0.60 \mathrm{Aa}$ \\
\hline Immersion on cold water $10^{\circ} \mathrm{C}$ for $24 \mathrm{~h}$ & $0.82 \mathrm{Aa}$ & $0.89 \mathrm{Aa}$ & $0.66 \mathrm{Ba}$ \\
\hline Immersion on cold water $10^{\circ} \mathrm{C}$ for $48 \mathrm{~h}$ & $0.62 \mathrm{Ab}$ & $0.69 \mathrm{Ab}$ & $0.80 \mathrm{Aa}$ \\
\hline Immersion on cold water $10^{\circ} \mathrm{C}$ for $72 \mathrm{~h}$ & $0.54 \mathrm{Ac}$ & $0.60 \mathrm{Ac}$ & $0.65 \mathrm{Aa}$ \\
\hline Immersion on boiling water at $100^{\circ} \mathrm{C} 5 \mathrm{~min}$ & $0.00 \mathrm{Af}$ & $0.00 \mathrm{Ae}$ & $0.00 \mathrm{Ac}$ \\
\hline Chemical scarification with sulphuric acid 5 min & $0.00 \mathrm{Af}$ & $0.00 \mathrm{Ae}$ & $0.05 \mathrm{Ac}$ \\
\hline Mechanical scarification with sandpaper & $0.24 \mathrm{Ae}$ & $0.36 \mathrm{Ad}$ & $0.38 \mathrm{Ab}$ \\
\hline Mechanical scarification with sandpaper and immersion on water for $24 \mathrm{~h}$ & $0.65 \mathrm{Bb}$ & $0.87 \mathrm{Aa}$ & $0.63 \mathrm{Ba}$ \\
\hline Mechanical scarification with sandpaper and immersion on $\mathrm{GA}_{3}$ & $0.34 \mathrm{Bd}$ & $0.60 \mathrm{Ac}$ & $0.43 \mathrm{Bb}$ \\
\hline
\end{tabular}

*Means followed by the same letter on the row (uppercase) and on the column (lowercase), not different from each other according to the Scott-Knott Test at $5 \%$ of error probability.

The treatment with immersion in sulphuric acid for five minutes had most of the diaspores rigid (hard) at the end of the evaluation period of the germination test, indicating that the scarification time was insufficient to increase the permeability of the membrane, allowing the water absorption and even causing damages to the embryo of the seed. A similar effect 
was observed by using the pre-germination treatment with immersion in boiling water for five minutes, whose water temperature possibly caused damages to the embryonic tissues, resulting on the lack of germination.

The mechanical (physical) dormancy is frequent on forest species, in which the growth of the embryo is limited due to an impermeable structure, which prevents the water absorption even under favorable environmental conditions (Souza et al., 2012; Venier et al., 2012; Nasr et al., 2013).

Previous studies recommended, for the $B$. riedelianum species, the use of immersion in water for 24 hours and mechanical scarification (Carvalho, 2003; Mori et al., 2012; Donazzolo et al., 2013). However, they found from 12 to $37 \%$ of germination, values that are expressively lower than the ones obtained on this research.

The use of mechanical scarification, as a pre-germination treatment, on this research, even when conducted on the region to the side of the peduncle, offered a reduction of the germination percentage, when compared to the methods of immersion in cold water, indicating that this procedure caused damages to the internal structure of the seeds, or it was not sufficient to overcome the barrier for water absorption.

Regardless of the treatments to overcome dormancy, on the mechanical scarification treatments with moistening of the substrate on a $\mathrm{GA}_{3}$ solution, there was no significant difference among the other substrates. The efficiency and facility to use vermiculite as the substrate on the germination test corroborates with the recommendation described for the B. riedelianum species on the Guidelines for the Analysis of Seeds of Forest Species (Brasil, 2013).

The GSI results (Table 1) showed the same trend observed for the germination with the treatments to overcome the dormancy, observing that the treatments of immersion in water at $100{ }^{\circ} \mathrm{C}$ and sulphuric acid for five minutes were responsible for the lower indexes for all substrates.

It is observed that the treatments to overcome the dormancy promoted different germination speed indexes for each substrate used. For the paper substrate, the highest GSI is attributed to the treatment of immersion in water for 24 hours. With sand, the immersion in water for 24 hours and scarification and immersion for $24 \mathrm{~h}$ stand out; for vermiculite, most of the treatments showed no differences in relation to each other.

In that sense, with the purpose of reducing the time to conduct the germination test, the treatment with immersion in cold water for 48 hours associated to the use of the vermiculite substrate is suggested for the germination test, since it resulted on a GSI of 0.80 and mean germination of $83 \%$.

The normal seedlings of $B$. riedelianum on the $24^{\text {th }}$ day after the installation of the experiment are represented on
Figure 2 A. According to the illustration of the morphology of these seedlings, all of them show an adequately developed primary root, hypocotyl, open cotyledons and leaf primordia. Some diaspores that emitted a radicle, but which did not emit the other essential structures, were considered as abnormal at the end of the experiment (Figure 2C). The main types of abnormalities found on the different treatments were: atrophied primary root (Figure $2 \mathrm{C}-\mathrm{I}$ ); lack of primary root (Figure 2C - I); disproportional primary root in relation to the other structures of the seedling (Figure 2C - III); short and thick primary root with negative geotropism (Figure 2C - IV); lack of defined primary root, and disproportional to the aboveground part (Figure 2C - V) (Brasil, 2009). In addition to the abnormalities mentioned, the necrosis and malformation of the radicle could be observed; this may have occurred due to the loss of humidity by the substrate, mainly on the paper substrate, harming the development of the seedlings.

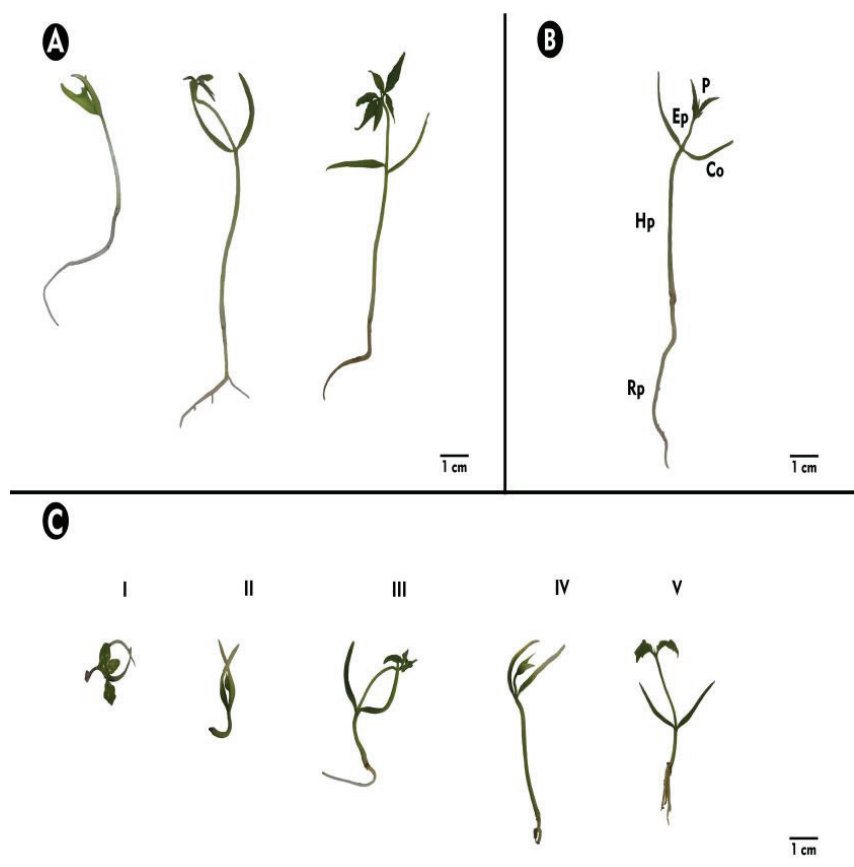

Figure 2. Seedlings of Balfourodendron riedelianum obtained on the germination test: A - Normal seedlings; B Normal seedling with primary root (Rp), hypocotyl (Hp), open cotyledons (Co), Epicotyl (Ep), protophil and first pair of leafs (P); C - Abnormal seedlings with atrophied primary root (I), lack of primary root (II), primary root not proportional in relation to the other structured of the seedling (III), short and thick primary root with negative geotropism (IV), lack of defined primary root, not proportional to the aboveground part (V). (Bars: $2 \mathrm{~cm}$ ). 
On seedlings considered as abnormal (Table 2), it was not possible to determine the direct relationship with the pregermination treatment. However, the treatments with immersion in cold water (24 and 48 hours) and mechanical scarification with posterior immersion in cold water for 24 hours showed the highest GSI values (Table 1) and abnormal diaspores.

Table 2. Pre-germination treatments on diaspores of Balfourodendron riedelianum associated to different substrates as an index of the physiological quality through the following variables: abnormal seedlings and hard diaspores.

\begin{tabular}{|c|c|c|}
\hline Treatments & Abnormal seedling (\%) & Hard diaspores $(\%)$ \\
\hline Control & $2.61 \mathrm{a}$ & $31.56 \mathrm{~b}$ \\
\hline Immersion on cold water at $10{ }^{\circ} \mathrm{C}$ for $24 \mathrm{~h}$ & $3.95 \mathrm{a}$ & $37.72 \mathrm{c}$ \\
\hline Immersion on cold water at $10{ }^{\circ} \mathrm{C}$ for $48 \mathrm{~h}$ & $3.52 \mathrm{a}$ & $14.40 \mathrm{a}$ \\
\hline Immersion on cold water at $10^{\circ} \mathrm{C}$ for $72 \mathrm{~h}$ & $2.97 \mathrm{a}$ & $40.37 \mathrm{c}$ \\
\hline Immersion on boiling water at $100{ }^{\circ} \mathrm{C} 5 \mathrm{~min}$ & $0.00 \mathrm{~b}$ & $100.00 \mathrm{e}$ \\
\hline Chemical scarification with sulphuric acid 5 min & $0.08 \mathrm{~b}$ & $97.00 \mathrm{e}$ \\
\hline Mechanical scarification with sandpaper & $1.64 \mathrm{~b}$ & $59.19 \mathrm{~d}$ \\
\hline Mechanical scarification with sand paper and water immersion & $3.59 \mathrm{a}$ & $47.25 \mathrm{c}$ \\
\hline Mechanical scarification with sandpaper and $\mathrm{GA}_{3}$ immersion & $2.29 \mathrm{a}$ & $58.13 \mathrm{~d}$ \\
\hline
\end{tabular}

*Means followed by the same (lowercase) letter on the column, not different from each other according to the Scott-Knott Test at $5 \%$ of error probability.

The percentage of hard diaspores is directly related to the efficiency of the methods used to overcome the dormancy; therefore, treatments with low germination indexes resulted on high percentages of hard diaspores.

\section{Conclusions}

The dimensions of the diaspores of Balfourodendron riedelianum are, on average, $18.59 \mathrm{~mm}$ long, $9.03 \mathrm{~mm}$ wide and $9.38 \mathrm{~mm}$ thick.

The dispersing unit of Balfourodendron riedelianum shows, as its dormancy mechanism, the inability of the wrap to soaking of water, which is overcome with immersion in cold water $\left(8 \pm 2{ }^{\circ} \mathrm{C}\right)$, for 48 hours, and the use of vermiculite as substrate for the germination test.

\section{Acknowledgements}

To the Forestry Laboratory and Forest Seedling Nursery of the Department of Forest Sciences and the Laboratory of Seeds of the Department of Plant Science, at Universidade Federal de Santa Maria (UFSM), Santa Maria, Rio Grande do Sul, for the use of its installations.

\section{References}

ALEXANDRE, R. S.; GONÇALVES, F. G.; ROCHA, A. P.; ARRUDA, M. P; LEMES, E Q. Tratamentos físicos e químicos na superação de dormência em sementes de Enterolobium contortisiliquum (Vell.) Morong. Revista Brasileira de Ciências Agrárias, v.4, n.2, p.156-159, 2015. http://www.agraria.pro.br/ojs2.4.6/index. php?journal=agraria\&page $=$ article $\&$ op $=$ view $\&$ path $\% 5 B \% 5 \mathrm{D}=1946$.
AZEREDO, G. A.; PAULA, R. C.; VALERI, S. V.; MORO, F. V. Superação de dormência de sementes de Piptadenia moniliformis Benth. Revista Brasileira de Sementes, v.32, n.2, p.49-58, 2010. http://www.scielo.br/pdf/ $\mathrm{rbs} / \mathrm{v} 32 \mathrm{n} 2 / \mathrm{v} 32 \mathrm{n} 2 \mathrm{a} 06 . p d f$.

BACKES, P.; IRGANG, B. Árvores do Sul. Guia de identificação \& interesse ecológico. As principais espécies nativas Sul-Brasileiras. 1.ed. Santa Cruz do Sul: Instituto Souza Cruz, 2002. 326p.

BIRUEL, R. P.; AGUIAR, I. B.; PAULA, R. C. Germinação de sementes de pau-ferro submetidas a diferentes condições de armazenamento, escarificação química, temperatura e luz. Revista Brasileira de Sementes, v.29, p.151-159, 2007. http://www.scielo.br/pdf/rbs/v29n3/a18v29n3.

BRASIL. Ministério da Agricultura, Pecuária e Abastecimento. Regras para análise de sementes. Ministério da Agricultura, Pecuária e Abastecimento. Secretaria de Defesa Agropecuária. Brasília: MAPA/ACS, 2009. 395p. http:// www.agricultura.gov.br/arq_editor/file/2946_regras_analise_sementes.pdf

BRASIL. Ministério da Agricultura, Pecuária e Abastecimento. Instruções para análise de espécies florestais. Brasília, DF: Agropecuária MAPA/ ACS, 2013. 98p. http://www.agricultura.gov.br/arq_editor/file/Laboratorio/ Sementes/FLORESTAL_documento_pdf.pdf

BRASIL. Ministério da Agricultura, Pecuária e Abastecimento. Instrução normativa $n^{\circ}$ 44. Brasília: MAPA, 2010. 2p. http://www.apps.agr.br/upload/ ax4_1109201248412700_anexo_in_44.pdf

BRASIL. Ministério da Agricultura, Pecuária e Abastecimento. Instrução normativa $n^{\circ}$ 34. Brasília: MAPA, 2011, 1p. http://www.apps.agr.br/site/ Conteudo/1727

BRASIL. Ministério da Agricultura, Pecuária e Abastecimento. Instrução normativa $n^{o}$ 26. Brasília: MAPA, 2012. 4p. http://www.lex.com.br/ legis_23721024_INSTRUCAO_NORMATIVA_N_26_DE_10_DE_ SETEMBRO_DE_2012.aspx

CAMPOS, L. F. C.; ABREU, C. M.; GUIMARAES, R. N.; SELEGUINI, A. Escarificação e ácido giberélico na emergência e crescimento de plântulas de biribá. Ciência Rural, v.45, n.10, p. 1748-1754, 2015. http:// http://www. scielo.br/pdf/cr/v45n10/1678-4596-cr-45-10-01748.pdf. 
CARVALHO, P. E. R. Espécies arbóreas brasileiras: recomendações silviculturais, potencialidades e uso da madeira. Brasília: Embrapa, Colombo, PR, Embrapa Florestas, 1039p. 2003.

DONAZZOLO, J.; ROQUE, A. A.; IORIS, E. G.; GUOLLO, K.; FELIPPI, M. POSSENTI, J. C. Germinação de sementes de Balfourodendron riedelianum (Engler) Engler: uma espécie ameaçada. Caderno de Agroecologia, v.8, n.2, 2013. http://www.aba-agroecologia.org.br/revistas/index.php/cad/article/view/15023.

DRESCH, D. M.; SCALON, S. D. P. Q.; MASETTO, T. E.; CARMO VIEIRA, M. Germinação de sementes de Campomanesia adamantium (Camb.) O. Berg em diferentes temperaturas e umidades do substrato. Scientia Forestalis, v.40, n.94, p.223-229, 2012. http://www.ipef.br/publicacoes/ scientia/nr94/cap09.pdf.

FERREIRA, D. F. Sisvar: a computer statistical analysis system. Ciência e Agrotecnologia, v.35, n. 6, p.1039-1042, 2011. http://www.scielo.br/pdf/ cagro/v35n6/a01v35n6.pdf.

FIGLIOLIA, M. B.; PIÑA-RODRIGUES, F. C. M. Manejo de sementes de espécies arbóreas. IF Série Registros, São Paulo: n.15, p.1-59, 1995.

GODOI, S.; TAKAKI, M. Effects of light and temperature on seed germination in Cecropia hololeuca Miq. (Cecropiaceae). Brazilian Archives of Biology and Technology, v.47, n.2, p.185-191, 2004. http://www.scielo.br/ scielo.php?script=sci_arttext\&pid=S1516-89132004000200004

GRINGS, M.; BRACK, P. Grupos de uso e as espécies prioritárias Balfourodendron riedelianum: guatambu. In: CORADIN, L.; SIMINSKI, A.; REIS, A. Espécies nativas da flora brasileira de valor econômico atual ou potencial: plantas para o futuro - Região Sul. Brasília: MMA, 2011. 934p.

GUEDES, R. S.; ALVES, E. U.; GONÇALVES, E. P.; BRAGA Jr., J. M.; VIANA, J. S.; COLARES, P. N. Q. Temperaturas e substratos para germinação e vigor de teste de Amburana cearensis (Allemão) AC Smith. Revista Árvore, v.34, n.1, p.57-64, 2010. http://www.scielo.br/scielo. php?script=sci_arttext\&pid=S0100-67622010000100007.

GUTTERMAN, Y. Maternal effects on seeds during development. In: FENNER, M. (Ed.). Seeds: the ecology of regeneration in plant communities. 2. ed. CAB International UK, p. 145-162, 1992.

LORENZI, H. Árvores brasileiras: manual de identificação e cultivo de plantas arbóreas nativas do Brasil. v.1, 5 ed. Nova Odessa, SP: Instituto Plantarum, 383p. 2008.

MAGUIRE, J. D. Speed of germination aid in selection and evaluation for seedling emergence and vigor. Crop Science, v.2, p.176-177, 1962. http:// dx.doi.org/10.2135/cropsci1962.0011183X000200020033x.

MARTINS, C. C.; MACHADO, C. G.; MATINELLI-SENEME, A.; ZUCARELI, C. Método de colheita de dormência na qualidade fisiológica de sementes de Cassia ferruginea. Semina, v. 33, n.2, p. 491-498, 2012. http://www.uel.br/revistas/wrevojs246/index.php/semagrarias/article/ download/6170/10439.
MORI, E. S.; PIÑA-RODRIGUES, F. C. M.; FREITAS, N. P. Sementes florestais: guia para germinação de 100 espécies nativas. São Paulo: Instituto Refloresta, 2012. 159p.

MUNSELL, A. H. Munsell color charts for plants tissues. Macbeth. Division of Margen Corporation. Baltimore: 1976.

NASR, S. M. H.; SAVADKOOHI, S. K.; AHMADI, E. Effect of different seed treatments on dormancy breaking and germination in three species in arid and semi-arid lands. Forest Science and Practice, v.15, n.2, p.130-136, 2013. http:// link.springer.com/article/10.1007\%2Fs11632-013-0209-7\#/page-1.

NOGUEIRA, F. C. B.; BEZERRA, M. L.; PINHEIRO, C. L.; BRITO, S. F.; MEDEIROS FILHO, S. Piptadenia stipulacea (Benth.) Ducke seed germination in response to temperature, light and water stress. American Journal of Plant Sciences, v.5, n.26, p.3796-3804, 2014. http://file.scirp.org/ pdf/AJPS_2014122214310304.pdf.

OLIVEIRA, A. K. M.; RIBEIRO, J. W. F.; PEREIRA, K. C. L.; RONDON, E. V.; BECKER, T. J. A.; BARBOSA, L. A. Superação de dormência em sementes de Parkia gigantocarpa (Fabaceae - Mimosidae). Ciência Florestal, v.22, n.3, p.533-540, 2012. http://www.redalyc.org/pdf/534/53423738010.pdf.

RODRIGUES, A. C. C.; OSUMA, J. T. A.; QUEIROZ, S. R. O. D.; RIOS, A. P. S. Biometria de frutos e sementes e grau de umidade de sementes de angico (Anadenanthera colubrina (Vell.) Brenan var. cebil (Griseb.) Altschul) procedentes de duas áreas distintas. Revista Científica Eletrônica de Engenharia Florestal, v.4,n.8,p.1-15,2006.http://faef.revista.inf.br/imagens arquivos/arquivos_destaque/kSbm7OyS25h0OGk_2013-4-26-10-50-41.pdf.

SANTOS, S. R. G.; AGUIAR, I. B. Germinação de sementes de branquilho (Sebastiania commersoniana (Baill.) Smith \& Downs) em função do substrato e do regime de temperatura. Revista Brasileira de Sementes, v.22, n.1, p.120126, 2000. http://www.abrates.org.br/revista/artigos/2000/v22n1/artigo17.pdf.

SENEME, A. M.; POSSAMAI, E.; VANZOLInI, S.; MARTINS, C. C. Germinação, qualidade sanitária e armazenamento de sementes de canafístula (Peltophorum dubium). Revista Árvore, v. 36, n.1, p.1-6, 2012. http://www. scielo.br/scielo.php?script=sci_arttext\&pid=S0100-67622012000100001.

SILVA, M. S.; BORGES, E. E. L.; LEITE, H. G.; CORTE, V. B. Biometria de frutos e sementes de Melanoxylon brauna Schott. (FabaceaeCaesalpinioideae). Cerne, v.19, n.3, p.517-524, 2013. http://www.scielo.br/ scielo.php?pid=S0104-77602013000300020\&script=sci_arttext.

SOUZA, T. V.; VOLTOLINI, C. H.; SANTOS, M.; PAULILO, M. T. S. Water absorption and dormancy-breaking requirements of physically dormant seeds of Schizolobium parahyba (Fabaceae -Caesalpinioideae). Seed Science Research, v.22, p.169-176, 2012. http://journals.cambridge.org/abstract S0960258512000013.

VENIER, P.; FUNES, G.; GARCÍA, C. C. Physical dormancy and histological features of seeds of five Acacia species (Fabaceae) from xerophytic forests in central Argentina. Flora, v.207, p. 36-46, 2012. http://www.scielo.br/pdf/jss/ v37n1/2317-1545-jss-v37n1140433.pdf. 